\title{
Note on Fieldwork
}

The ethnographic material documented and analysed in this book was collected for the most part during a series of fieldwork visits made between December 2015 and September 2019 to commercial nodes important for Afghan merchants across Eurasia. I conducted fieldwork with Afghan traders in Yiwu between February and July 2016 and revisited the city in January 2018, August-September 2018 and September 2019. During this period, I also visited Guangzhou and Hong Kong in order to meet traders with businesses interests in Yiwu. I conducted fieldwork in the Zeytinburnu neighbourhood of Turkey in July and October 2016 and July-August in 2017, and made a brief visit in May 2019. In November-December 2016, I interviewed Afghan and 'Bukharan' traders in Jeddah and Riyadh in Saudi Arabia. I made fieldwork visits to Odessa in Ukraine during August-September 2016 and August 2018, and met traders and Afghan community members in Kiev in June 2017. In December 2015 and June 2017, I interviewed Afghan traders in St Petersburg. I conducted fieldwork in Afghanistan in October 2016 (visiting Kabul and Mazar-e Sharif), SeptemberOctober 2017 (Kabul, Herat, Mazar-e Sharif and Andkhuy), September 2018 (Kabul and Panjshir), and August 2019 (Kabul, Herat and Panjshir).

I also made a series of short visits to nodes of significance for Afghan trading networks in order to meet traders previously known to me and to map the commercial activities of the trading networks of which they formed a part. I visited sites of significance to Afghan trading networks in Karachi in November 2017, especially the Sohrab Goth neighbourhood. Between May 2017 and September 2019, I made intermittent visits to wholesale markets in London (especially Southall and the Mile End Road areas) and Manchester (especially Cheetham Hill) in order to interview Afghan traders with whom I established contact in Yiwu. I also visited De Bazaar in Beverwijk, the Netherlands, in November 2018, and met merchants of Afghan Jewish and Muslim 
background in New York and New Jersey in October-November 2019. During the course of a short visit to attend a conference in Japan in July 2016 I visited Cheba prefecture in order to meet Afghan traders based in the region. During the course of stopovers in Dubai en route to Kabul I was able to meet Afghan traders involved in Eurasia, most notably in Deira.

During the course of specific research visits to China, Russia and Turkey detailed above, I benefited from the co-presence of team members working on related but distinct aspects of the TRODITIES project. Most notably, I conducted spells of research alongside Diana IbañezTirado in China, Ukraine, Turkey and Russia, Vera Skvirskaja in Russia and Paul Anderson and Huaichuan Rui in China.

In addition to these periods of fieldwork, the ethnographic material explored in the book builds on my engagement since 1995 with both Afghanistan and Pakistan - detailed descriptions of fieldwork conducted prior to 2015 can be found in my earlier publications. ${ }^{1}$

\footnotetext{
${ }^{1}$ See Marsden 2005 and Marsden 2016.
} 